Article

\title{
First Description of the Composition and the Functional Capabilities of the Skin Microbial Community Accompanying Severe Scabies Infestation in Humans
}

\author{
Charlotte Bernigaud ${ }^{1,2,3,+}$, Martha Zakrzewski ${ }^{4,+}$, Sara Taylor ${ }^{1}$, Pearl M. Swe ${ }^{1}$ (D) Anthony T. Papenfuss ${ }^{5,6}$, \\ Kadaba S. Sriprakash ${ }^{1}$, Deborah Holt ${ }^{7}$, Olivier Chosidow ${ }^{2,3}$, Bart J. Currie ${ }^{7,8} \mathbb{D}^{\mathbb{D}}$ and Katja Fischer ${ }^{1, *}$
}

1 Scabies Laboratory, Infectious Diseases Program, Biology Department, QIMR Berghofer Medical Research Institute, Brisbane 4006, Australia; charlotte.bernigaud@aphp.fr (C.B.);

Sara.Taylor@qimrberghofer.edu.au (S.T.); Pearl.Swe-Kay@qimrberghofer.edu.au (P.M.S.); sri.sriprakash@qimrberghofer.edu.au (K.S.S.)

2 APHP, Hôpital Henri-Mondor, Department of Dermatology, Université Paris-Est, 94000 Créteil, France; olivier.chosidow@aphp.fr

3 Research Group Dynamic, EA7380, Faculté de Santé de Créteil, Ecole Nationale Vétérinaire d'Alfort, USC ANSES, Université Paris-Est Créteil, 94000 Créteil, France

4 Genetics and Computational Biology Department, QIMR Berghofer Medical Research Institute, Brisbane 4006, Australia; Martha.Zakrzewski@qimrberghofer.edu.au

check for updates

Citation: Bernigaud, C.; Zakrzewski, M.; Taylor, S.; Swe, P.M.; Papenfuss, A.T.; Sriprakash, K.S.; Holt, D.; Chosidow, O.; Currie, B.J.; Fischer, K. First Description of the Composition and the Functional Capabilities of the Skin Microbial Community

Accompanying Severe Scabies Infestation in Humans. Microorganisms 2021, 9, 907. https:// doi.org/10.3390/microorganisms 9050907

Academic Editor: Holger Brüggemann

Received: 16 March 2021

Accepted: 20 April 2021

Published: 23 April 2021

Publisher's Note: MDPI stays neutral with regard to jurisdictional claims in published maps and institutional affiliations.

Copyright: (c) 2021 by the authors. Licensee MDPI, Basel, Switzerland. This article is an open access article distributed under the terms and conditions of the Creative Commons Attribution (CC BY) license (https:/ / creativecommons.org/licenses/by/ $4.0 /)$.
5 Bioinformatics Division, The Walter and Eliza Hall Institute of Medical Research, Parkville 3052, Australia; papenfuss@wehi.edu.au

6 Department of Medical Biology, University of Melbourne, Melbourne 3010, Australia

7 Menzies School of Health Research, Charles Darwin University, Darwin 0810, Australia; Deborah.Holt@menzies.edu.au (D.H.); Bart.Currie@menzies.edu.au (B.J.C.)

8 Department of Infectious Diseases, Royal Darwin Hospital, Darwin 0810, Australia

* Correspondence: Katja.Fischer@qimrberghofer.edu.au

$\dagger$ Authors contributed equally to this article.

\begin{abstract}
Epidemiological studies link Sarcoptes scabiei infection and impetigo. Scabies mites can promote Streptococcus pyogenes (Group A Streptococcus) and Staphylococcus aureus infections by breaching the skin barrier and excreting molecules that inhibit host innate immune responses. However, little is known about the composition and the function of the scabies-associated microbiota. Here, highthroughput whole-metagenome sequencing was used to explore the scabies-associated microbiome. Scabies mites including their immediate microenvironments were isolated from two patients with severe scabies in Northern Australia. Two $\sim 45-50$ million paired-end reads Illumina libraries were generated of which $\sim 2(5.1 \%)$ and 0.7 million (1.3\%) microbial reads were filtered out by mapping to human (hg19) and mite draft genomes. Taxonomic profiling revealed a microbial community dominated by the phylum Firmicutes (A: 79\% and B: 59\%) and genera that comprise Streptococcus, Staphylococcus, Acinetobacter, and Corynebacterium. Assembly of the metagenome reads resulted in genome bins representing reference genomes of Acinetobacter baumannii, Streptococcus dysgalactiae (Group C/G), Proteus mirablis and Staphylococcus aureus. The contigs contained genes relevant to pathogenicity and antibiotics resistance. Confocal microscopy of a patient skin sample confirmed A. baumannii, Streptococci and S. aureus in scabies mite gut and faeces and the surrounding skin. The study provides fundamental evidence for the association of opportunistic pathogens with scabies infection.
\end{abstract}

Keywords: scabies; Sarcoptes scabiei; microbiota; microbiome; skin microbiota; skin microbiome; Acinetobacter; GAS; Streptococcus; metagenomic

\section{Introduction}

Scabies is a parasitic skin infection caused by the mite Sarcoptes scabiei var. hominis in humans. The parasite reproduces in the skin and causes a spectrum of diseases from 
common scabies, with less than a dozen mites over the entire body, to severe profuse and crusted forms, where the number of infesting mites can reach millions [1,2]. With an estimated 200 million cases annually, scabies causes a significant global disease burden worldwide [3,4]. Scabies occurs globally, but is more prevalent in tropical and subtropical countries, and in overcrowded and socially disadvantaged communities [3-5]. For example, among Indigenous communities of northern Australia, the scabies prevalence can be as high as $50 \%$ in children and $25 \%$ in adults $[5,6]$. In these communities, scabies has a substantial impact on the health and quality of life of people [3]. Most important, secondary bacterial infections can cause serious complications, in addition to itch-related sleep disturbances, social stigma, school and job absenteeism, and increased poverty resulting from chronic disability [3,7].

The human skin is a complex interface between the host and the environment, forming a barrier to infectious microorganisms and playing an important role between the resident skin microbiota, and the host immune response. The microbiota of healthy skin is comprised of taxonomically and functionally diverse microorganisms, most of which are benign commensals residing in epidermal and sub epidermal layers [8]. Skin microbiota composition is multifaceted, shaped by many factors, and highly specific to each individual, and micro-organisms are distributed on the body surface in physiological and topographical distinct niches [9]. When scabies mites enter the epidermis, the alteration of the skin barrier due to burrowing by the mite and scratching by the host often leads to infections with opportunistic pathogens. The major bacteria causing pyoderma (i.e., infection of the epidermal and subepidermal layers of the skin, also called impetigo or skin sores) are Streptococcus pyogenes (Group A Streptococcus, GAS) and Staphylococcus aureus [10]. Once in the skin, these pathogens can cause invasive and severe infections, which are potentially fatal [11]. Post-infectious sequelae associated with GAS include autoimmune-mediated diseases such as acute post-streptococcal glomerulonephritis and acute rheumatic fever [12], which can cause further chronic disease [12]. The prevalence of these diseases in Australian Indigenous communities are amongst the highest in the world, leading to a long-term burden and considerable morbidity, especially in children [13]. Worldwide, GAS remains in the top ten global causes of mortality with an estimated 500,000 deaths a year [12,14]. In 2015, rheumatic heart disease was estimated to be responsible for 319,400 deaths [15,16]. Additionally, patients with severe forms of scabies (i.e., crusted scabies) often present with S. aureus bacteraemia [11], leading to potentially life-threatening sepsis $[17,18]$.

Although previous epidemiological studies have clearly identified a link between the epidermal infestation with S. scabiei and impetigo [19-26], the molecular pathways linking bacterial pathogens and the scabies mite are still poorly understood. Recent in vitro molecular studies have shown an intriguing tripartite interaction between scabies mites, associated opportunistic bacteria, and the human host [27-30]. In particular, scabies mites release several classes of intestinal complement inhibiting proteins that are located into the epidermis [31-34]. These complement inhibitors have been shown to indirectly promote the growth of various GAS [28] and S. aureus [29] clinical isolates. In whole blood bacterial assays, complement inhibitors reduce the opsonisation of the bacteria surfaces and thereby decrease phagocytosis by the neutrophils. Indeed, through this mechanism, the mite itself may play a role in the establishment, proliferation, and transmission of GAS and S. aureus associated with scabies.

Little is known about the composition of the mite surrounding skin microbiota during a scabies infestation and its functional capabilities. Additional pathogenic bacteria other than GAS and S. aureus could be present. In this study, high-throughput whole metagenome sequencing was employed to explore the scabies-associated microbiome in two human patients with crusted scabies. The aim of the study was to provide a first snapshot of the microbiota associated with scabies infection in humans and of the roles these bacteria play in pathogenesis. 


\section{Materials and Methods}

\subsection{Patients and Sample Collection}

The collection of the human patient samples was approved by the Human Research Ethics Committee of the Northern Territory Department of Health and Menzies School of Health Research and Menzies School of Health Research (approval 13-2027). Informed consent was obtained from each patient recruited into the study.

Scabies mites were isolated from skin scrapings collected from two unrelated patients with crusted scabies (Patient A and Patient B) from different regional areas of the Northern Territory, Australia. Patient A was a 26-year-old female and Patient B was a 54-yearold male. Over 20 years, both patients had presented with recurrent crusted scabies on multiple occasions. Patient B was one of the two original patients with documented clinical and in vitro ivermectin resistance following prior multiple intermittent therapy with ivermectin [35]. Both patients presented with clinical grade 3 crusted scabies at the time of sampling $[2,36]$. Neither patient had an identified immunosuppressive comorbidity although both had high serum IgE levels as seen almost universally in crusted scabies [18]. Prior to sampling, the skin was not washed, disinfected or otherwise treated, and no topical or oral antibiotics were administered. Scabies mites (S. scabiei var. hominis) were individually picked from skin samples collected by scraping the skin of each patient and were pooled. Each skin sample contained between 800 and 1000 mites of all life stages. Pooled isolated mites with their skin microenvironments were not washed to explore both the mite internal and the mite surrounding skin microbiomes.

\subsection{DNA Extraction and Whole Genome Sequencing}

DNA from the mites and their skin environment was extracted from each sample using a Blood and Cell Culture DNA Kit (Qiagen, Chadstone, Victoria, Australia) and a modified procedure, adapted from the manufacturer's protocol. This protocol is detailed in Mofiz et al. [37,38]. Briefly, samples were immerged in $1 \mathrm{~mL}$ of ice-cold lysis buffer $(20 \mathrm{mM}$ EDTA, $100 \mathrm{nM} \mathrm{NaCl}$, 1\% TritonX-100, $500 \mathrm{mM}$ Guanidine-HCl, $10 \mathrm{mM}$ Tris pH 7.9) and homogenized with stainless steel beads of $2.8 \mathrm{~mm}$ diameter at $6800 \mathrm{rpm}, 3$ cycles, $30 \mathrm{sec}$ per cycle, $30 \mathrm{sec}$ between cycles. The suspension was supplemented with DNase-free RNase A to $0.2 \mathrm{mg} / \mathrm{mL}$ and with Proteinase $\mathrm{K}$ to $0.8 \mathrm{mg} / \mathrm{mL}$ and incubated at $50{ }^{\circ} \mathrm{C}$ for $1.5 \mathrm{~h}$. After centrifugation at $4000 \times g$ for $10 \mathrm{~min}$ to pellet insoluble debris, the genomic DNA was isolated on the Qiagen genomic tip as instructed in the manufacturer's protocol. Two DNA libraries were constructed and 100-base pair paired-end reads were generated on an Illumina HiSeq 2500 instrument at the Australian Genome Research Facility of Melbourne, Victoria, Australia.

\subsection{Read Pre-Processing}

Raw sequencing data was processed for removal of Illumina adaptor sequences, trimmed and quality-based filtered using TRIMMOMATIC software v.0.32 [39] (LEADING:3 TRAILING:3 SLIDINGWINDOW:4:15 MINLEN:30). Paired-end reads were merged using PEAR v.0.9.6 [40]. Scabies mite reads were filtered out by applying BWA-MEM v.0.7.12 [41] using a database of the recently published scabies draft genomes [38,42]. Prior to mapping the sequenced paired reads, the scaffolds of the published draft genomes were examined for microbial contamination by searching for matches to a bacterial, fungal or archaeal NCBI nucleotide sequence using BLAST ( $>80 \%$ nucleotide identity and $25 \%$ scaffold coverage) [43]. Reads that did not match the scabies genomes were subsequently mapped to the human assembly GRCh37 (Hg19) using BWA-MEM v.0.7.12 to identify, and remove human host genome contamination.

\subsection{Whole Metagenome Shotgun Profiling and Binning}

The bacterial taxonomic composition and community abundances of the samples were determined using the software KRAKEN v.0.10.5 [44]. The protein alignment tool DIAMOND was applied with an e-value of $10^{-5}$ to search for sequence matches in the 
NCBI protein reference database (downloaded 18 March 2016) and to identify the fungal taxonomic composition and abundances [45]. The read sequences were assigned to the taxonomic lowest common ancestor (LCA) using hits whose scores lie within $10 \%$ of the best score. The taxonomic assignments were visualised in Krona charts [46]. Reads were assembled using metaspades v3.12 with automatic k-mer sizes adjustment [47]. Metabat2.12.1 was used for binning [48] and checkM v.1.0.14 to assign the bins in taxonomic hierarchy [49]. Contigs in each bin were searched for matches to reference nucleotide sequences in NCBI using BLAST. Genes were predicted and translated into proteins using MetaGeneMark [50].

\subsection{Bacterial Strain Variation Analysis}

Four of the identified bacteria species, which had a predicted assembled completeness of $>92 \%$, were selected to be defined at the strain level. The tool PanPhlAn v1.2.2.5 [51] was applied using reference genomes from NCBI (ftp:/ / ftp.ncbi.nlm.nih.gov/genomes/ all/GCF) for Acinetobacter baumannii (downloaded 10/01/21), S. dysgalactiae (25/02/19), S. aureus $(25 / 02 / 19)$ and Proteus mirablis (26/02/19). PanPhlAn profiles different reference strains of a species according to their gene content, which are used as a reference to identify the strain in a metagenomic data. Multi-locus sequence typing (MLST) analysis was done using PubMLST (https:/ / pubmlst.org).

2.6. Virulence Factors, Antibiotic Resistance, Degradome and Metabolic Pathway Analysis of the Bacterial Communities

Microbial contigs were searched for matches to the virulence gene sequences obtained from the Virulence Factor Database (VFDB) (downloaded 18/02/18) using BLAST [52]. In addition, metagenome reads were mapped against the virulence factor gene $\mathrm{emm}$ of S. pyogenes (gb | NP_608047) using BWA-MEM [41]. Antibiotic resistance in the assembled metagenome was analysed using the Comprehensive Antibiotic Resistance Database (CARD) (version 3.0.1). SCCmecFinder was used to identify the type of Staphylococcal cassette chromosome mec [53]. The degradome was analysed using the MEROPS database (Release 12.1) by searching for matching genes annotated on the metagenome-assembled genomes using BLAST [54]. Genes and contigs were mapped to KEGG Metabolic pathways (https://www.kegg.jp/) using BLAST.

2.7. Localisation of A. baumannii, S. pyogenes, S. dysgalactiae, and S. aureus in the Scabies Mite and in the Surrounding Human Skin

The bacteria of interest were searched and localised within the scabies mites and in the surrounding skin using skin sections obtained from Patient $B$ probed with bacteria-specific antibodies, i.e., A. baumannii polyclonal anti-rabbit antibodies (Life span Biosciences, Seattle, WA, USA), S. pyogenes polyclonal anti-goat antibodies (My BioSource, San Diego, CA, USA), and S. aureus polyclonal anti-rabbit antibodies (My BioSource, San Diego, CA, USA). Goat Streptococcus Group A polyclonal antibody (MBS535099, My BioSource, San Diego, CA, USA) was used to localise both S. pyogenes and S. dysgalactiae.

\subsubsection{Testing of the Specificity of Primary Antibodies}

Primary antibodies were tested using reference strains (A. baumannii ATCC19606, S. pyogenes 2031 Type strain emm1, S. dysgalactiae NS3396 emm-type STG-480, and S. aureus MSSA CC75 M5) grown in Tryptic Soy Broth (Oxoid). Using cavity well slides (Proscitech), $20 \mu \mathrm{L}$ volumes of bacterial cultures at an OD600 0.1 were incubated on the slide at $37^{\circ} \mathrm{C}$ for $24 \mathrm{~h}$, with A. baumannii and S. aureus incubated aerobically, and S. pyogenes and S. dysgalactiae slides incubated in $5 \% \mathrm{CO}_{2}$. After incubation, the slides were heat fixed, then further fixed in $100 \%$ methanol for $1 \mathrm{~min}$. After fixation, the staining protocol was carried out as previously outlined, and controls were included by staining each bacterial strain with all three primary antibodies to ensure that there was no cross-reactivity between each strain. Using the Zeiss 780-NLO (North Ryde, New South Wales, Australia) confocal microscope 
no cross-reactivity was seen, and staining of the appropriate bacteria with the appropriate antibody was demonstrated (Supplementary File, Figure S1).

\subsubsection{Localisation of the Bacteria of Interest}

To localise mite gut tissue, adjacent serial sections were probed with anti-human Immunoglobulin G (IgG), which is known to be ingested by the mite [55]. Adjacent serial sections were also probed with pre-immune mouse serum as a negative control. Paraffin blocks of $5 \mathrm{~mm}^{3}$ skin tissues were used to cut $4 \mu \mathrm{m}$ sections and coated on X-Tra ${ }^{\mathrm{TM}}$ (Leica Biosystems, Wetzlar, Germany) glass slides [56]. The slides were dried at $37^{\circ} \mathrm{C}$ for $3 \mathrm{~h}$ and dewaxed in xylene followed by graded ethanol. All the incubation steps were done at room temperature (RT) in a humidifier chamber and all the washes were $3 \times$ of 5 min with Tris Buffered Saline (TBS pH 7.6). Non-specific protein binding was blocked in $2 \%$ BSA in PBS (pH 7.4) for 30 min at RT. The primary antibodies were diluted to $1: 500$ in $1 \%$ BSA + PBS to a final concentration of $6 \mu \mathrm{g} / \mathrm{mL}$ A. baumannii antibodies, $1 \mu \mathrm{g} / \mathrm{mL}$ of $S$. pyogenes antibodies, and $8 \mu \mathrm{g} / \mathrm{mL}$ of $S$. aureus antibodies. Primary antibodies were incubated overnight at $4{ }^{\circ} \mathrm{C}$ in a humidified box. The following morning, primary antibodies were decanted, and the slides were washed in $3 \times$ changes of TBS-T for $5 \mathrm{~min}$. After washing the slides exposed to $A$. baumannii and $S$. aureus antibodies were incubated with secondary Alexafluor 555-labelled donkey anti-rabbit antibodies (Invitrogen, Waltham, MA, USA) diluted 1:1000 (2 $\mu \mathrm{g} / \mathrm{mL})$ in PBS, and the slides exposed to S. pyogenes antibodies were incubated with Alexafluor 488-labelled secondary donkey anti-goat antibodies (Invitrogen) diluted to 1:1000 (2 $\mathrm{gg} / \mathrm{mL})$. Secondary antibody incubation was for $2 \mathrm{~h}$ at RT in a dark humidified box. The secondary antibodies were decanted and the slides washed $3 \times$ in PBS for $5 \mathrm{~min}$. The slides were incubated in the dark for $10 \mathrm{~min}$ in $1 \mu \mathrm{g} / \mathrm{mL}$ of DAPI stain (Sigma Aldrich). The slides were mounted in fluromount aqueous mounting media (Sigma Aldrich) and kept in the dark for the coverslip to set. The slides were imaged using a Zeiss 780-NLO confocal microscope and analysed using Image J software.

An additional serial tissue section was either standard Hematoxylin/eosin (H\&E)stained, to visualise the mite morphology, or probed with an anti-human IgG antibody to highlight the mite digestive system [55]. For the latter, endogenous peroxidase activity was quenched using $5 \% \mathrm{H}_{2} \mathrm{O}_{2}$ for 5 min. Slides were washed with 3 rinses of TBS for 5 min, blocked with rabbit serum (1:10 dilution in PBS) for $30 \mathrm{~min}$ at RT and washed with 3 rinses of TBS for $5 \mathrm{~min}$. Slides were incubated with horseradish peroxidase (HRP) labelled anti-human IgG (Sigma Aldrich, St. Louis, MO, USA) for $1 \mathrm{~h}$ at RT, followed by a wash with 3 washes in TBS. Nova-RED substrate (VECTOR, California, USA) was added to initiate the chromogenic reaction and was stopped by immersion in deionised water for $3 \mathrm{~min}$ at RT. The slides were counterstained with haematoxylin for $1 \mathrm{~min}$, dehydrated in graded ethanol, cleared in xylene and mounted with DPX histology slide mounting medium (Sigma Aldrich, St. Louis, MO, USA). Slides were visualised using an Aperio XT Scanscope (Leica Biosystems, Wetzlar, Germany) slide scanner at $40 \times$ magnification and analysed using eSlide manager and ImageScope viewing software (Leica Biosystems, Wetzlar, Germany).

\section{Results}

\subsection{Pipeline}

The bioinformatic pipeline illustrating the steps and read counts is shown in Figure 1. Two $\sim 5$ to 50 million paired-end read Illumina libraries were generated, of which $\sim 2$ million $(5.09 \%)$ and 0.7 million $(1.32 \%)$ microbial reads were filtered out by mapping to the human genome (hg19) and the available draft mite genomes [38,42] (Figures 1 and 2). 
Sample A

53,699,468 PE reads (100 bp)

\section{2,342,462 PE reads}

40,402,453 PE reads

22,771,302 PE reads

2,243,558 PE reads

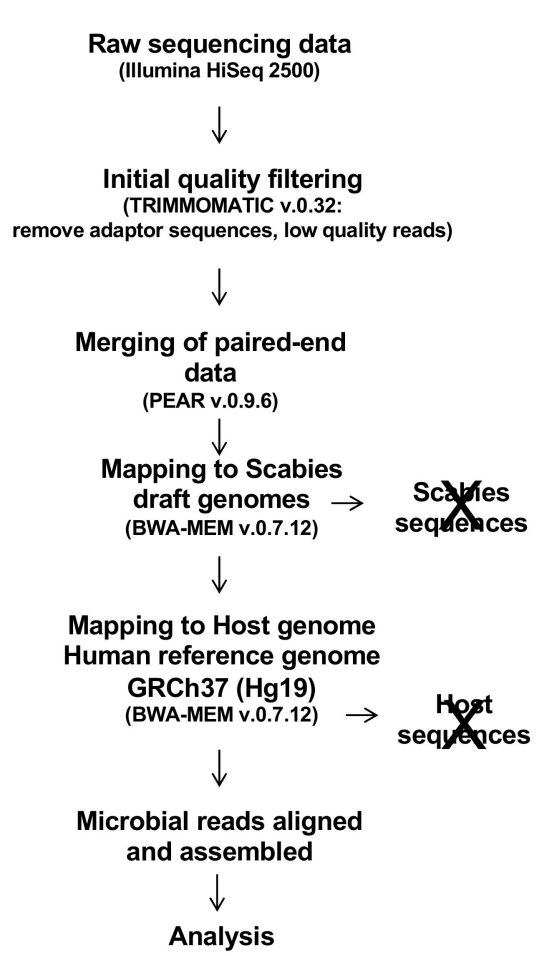

Sample B

45,851,518 PE reads

(100 bp)

44,434,781 PE reads

39,543,204 PE reads

8,409,696 PE reads

694,416 PE reads

Figure 1. The bioinformatic pipeline illustrating the different steps and the obtained read counts.

Sample A

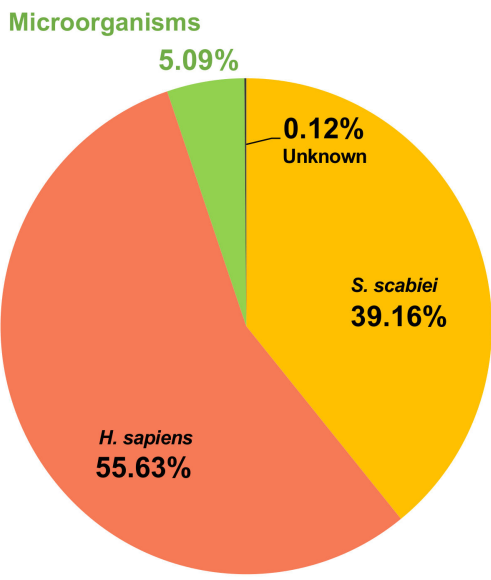

Sample B

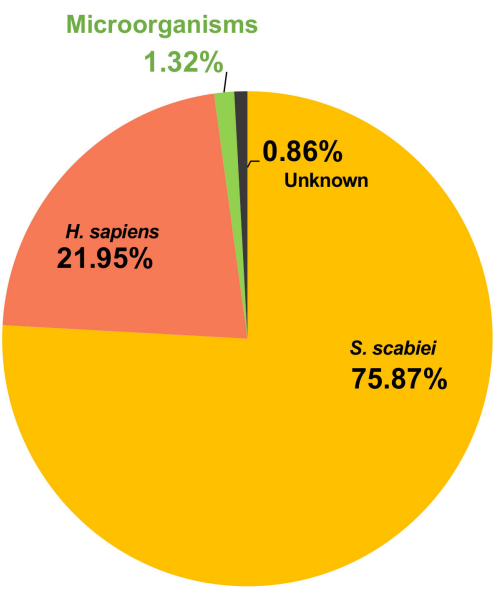

Figure 2. The repartition of the reads sequenced from each patient sample (Patient A and B). Two $\sim 45$ to 50 million paired-end read Illumina libraries were generated, of which 2 million (5.09\%) for Patient A and 0.7 million (1.32\%) for Patient B were attributed to microbial reads. The other reads were corresponding to human genome (H. sapiens) or mite genome (S. scabiei) sequences. A small proportion could not be attributed (unknown).

\subsection{Microbial Communities: Taxonomic Composition of the Metagenome}

Taxonomic profiling revealed a complex bacterial community in the samples derived from both patients. At the phyla level, Proteobacteria, Firmicutes and Actinobacteria comprised about $99 \%$ of all microbial reads, with the community being dominated by the phylum Firmicutes (Patient A: 79\% and Patient B: 59\%). The phylum Actinobacteria (Patient A: 9.4\% and Patient B: $11.9 \%$ ), which is known to be most prevalent in normal 
skin [9], was underrepresented in both patient samples. The pie charts in Figure 3 show differences in the bacterial communities' composition, indicating the 10 most abundant genera across the two patients. The most abundant genera in the skin sample from Patient A were Acinetobacter (81.2\%), Corynebacterium (8.1\%), Staphylococcus (4.2\%) and Streptococcus $(4 \%)$. In contrast, the microbiome sampled from Patient B was predominantly composed of Proteus (36.7\%), Staphylococcus (28.7\%), followed by Pseudomonas (9.8\%) and Corynebacterium $(9.6 \%)$ at the genus level. In the samples from both patients, the most abundant bacteria are known skin pathobionts that have disease-causing potential. Table 1 presents the most abundant species in both patients.

\section{Sample A}

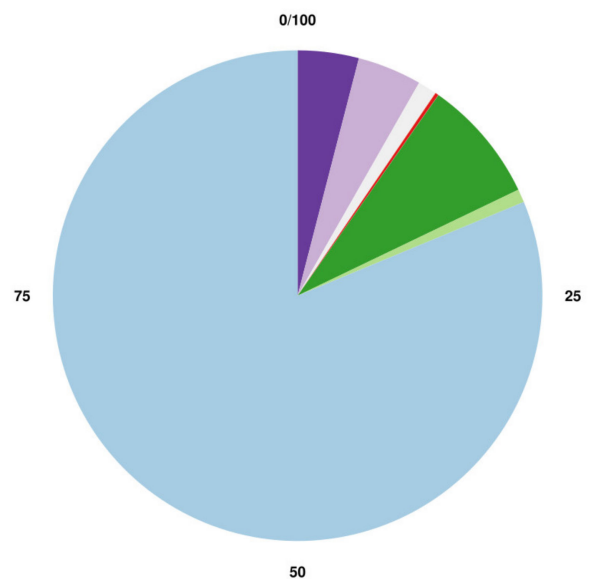

Sample B

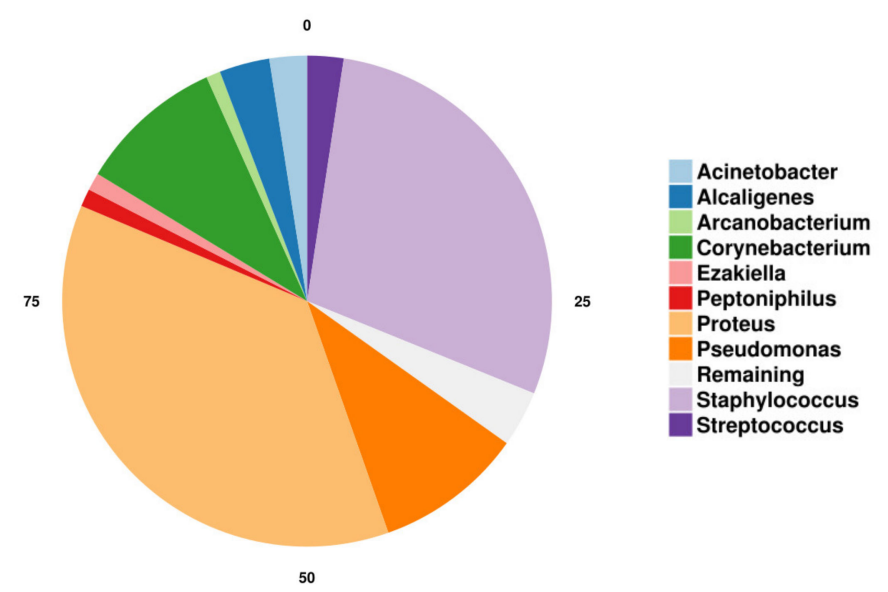

Figure 3. Distribution of the Top 10 most abundant taxa found in samples from Patients A and B at the genus level. The most abundant genera in Patient A sample comprise Acinetobacter in light blue (81.2\%), Corynebacterium in dark green (8.1\%), Staphylococcus in light purple (4.2\%), and Streptococcus in dark purple (4\%). The most abundant genera in Patient B sample comprise Proteus in light orange (36.7\%), Staphylococcus in light purple (28.7\%), followed by Pseudomonas in dark orange $(9.8 \%)$ and Corynebacterium in dark green $(9.6 \%)$.

Eukaryotic fungi were among the rare taxa with less than $0.01 \%$ of all classified reads. The most prevalent eukaryotic genus was Malassezia. Archaea were absent. Whole-genome shotgun metagenomics allowed the exploration of viral DNA present, which were mainly phages of S. pyogenes found in the sample from Patient B and Acinetobacter phages in the samples from both patients.

Table 1. Relative abundance (\%) of the bacterial species found in samples from Patient A and Patient B. Only species present with an abundance $>0.01 \%$ are shown.

\begin{tabular}{ccc}
\hline Species & $\begin{array}{c}\text { Sample from } \\
\text { Patient A }\end{array}$ & $\begin{array}{c}\text { Sample from } \\
\text { Patient B }\end{array}$ \\
\hline Acinetobacter_baumannii & 59.77 & 1.1 \\
Proteus_mirabilis & 0.01 & 41.09 \\
Staphylococcus_aureus & 3.38 & 23.9 \\
Streptococcus_dysgalactiae & 5.54 & 1.88 \\
Pseudomonas_aeruginosa & 0.00 & 5.75 \\
Corynebacterium_striatum & 5.28 & 0.17 \\
Corynebacterium_jeikeium & 0.87 & 5,00 \\
Staphylococcus_pettenkoferi & 0.02 & 4.28 \\
Acinetobacter_nosocomialis & 4.17 & 0.08 \\
Alcaligenes_faecalis & 0.00 & 3.26 \\
Acinetobacter_pittii & 3.18 & 0.06 \\
\hline
\end{tabular}


Table 1. Cont.

\begin{tabular}{|c|c|c|}
\hline Species & $\begin{array}{l}\text { Sample from } \\
\text { Patient A }\end{array}$ & $\begin{array}{c}\text { Sample from } \\
\text { Patient B }\end{array}$ \\
\hline Corynebacterium_diphtheriae & 2.66 & 1.55 \\
\hline Corynebacterium_resistens & 2.65 & 0.26 \\
\hline Staphylococcus_argenteus & 2.59 & 0.1 \\
\hline Acinetobacter_calcoaceticus & 1.45 & 0.03 \\
\hline Arcanobacterium_haemolyticum & 1.41 & 1.06 \\
\hline Ezakiella_massiliensis & 0.02 & 1.3 \\
\hline Peptoniphilus_harei & 0.34 & 1.25 \\
\hline Acinetobacter_soli & 1.23 & 0.02 \\
\hline Finegoldia_mäna & 1.02 & 0.3 \\
\hline Corynebacterium_xerosis & 0.35 & 0.85 \\
\hline Corynebacterium_aurimucosum & 0.05 & 0.68 \\
\hline Acinetobacter_lactucae & 0.67 & 0.02 \\
\hline Staphylococcus_cohnii & 0.00 & 0.64 \\
\hline Porphyromonas_asaccharolytica & 0.00 & 0.6 \\
\hline Acinetobacter_oleivorans & 0.4 & 0.01 \\
\hline Achromobacter_xylosoxidans & 0.00 & 0.4 \\
\hline Acinetobacter_sp._ACNIH1 & 0.38 & 0.1 \\
\hline Peptostreptococcaceae_bacterium_oral_taxon_929 & 0.01 & 0.38 \\
\hline Corynebacterium_simulans & 0.37 & 0.13 \\
\hline Staphylococcus_epidermidis & 0.03 & 0.36 \\
\hline Fastidiosipila_sanguinis & 0.35 & 0.14 \\
\hline Anaerococcus_mediterraneensis & 0.08 & 0.32 \\
\hline Streptococcus_pyogenes & 0.08 & 0.27 \\
\hline Corynebacterium_urealyticum & 0.03 & 0.27 \\
\hline Corynebacterium_sp._ATCC_6931 & 0.07 & 0.25 \\
\hline Alcaligenes_aquatilis & 0.00 & 0.2 \\
\hline Acinetobacter_sp._FDAARGOS_493 & 0.19 & 0,00 \\
\hline Staphylococcus_capitis & 0.19 & 0.09 \\
\hline Campylobacter_ureolyticus & 0.00 & 0.18 \\
\hline Anaerococcus_prevotii & 0.05 & 0.15 \\
\hline Acinetobacter_sp._WCHA55 & 0.15 & 0,00 \\
\hline Corynebacterium_lactis & 0.14 & 0.08 \\
\hline Escherichia_coli & 0.00 & 0.13 \\
\hline Staphylococcus_haemolyticus & 0.08 & 0.11 \\
\hline Acinetobacter_schindleri & 0.01 & 0.1 \\
\hline Streptococcus_pseudoporcinus & 0.01 & 0.1 \\
\hline Brevibacterium_linens & 0.02 & 0.09 \\
\hline Providencia_stuartii & 0.00 & 0.09 \\
\hline Corynebacterium_singulare & 0.03 & 0.08 \\
\hline Acinetobacter_junii & 0.08 & 0.01 \\
\hline Corynebacterium_falsenii & 0.01 & 0.08 \\
\hline Staphylococcus_sciuri & 0.01 & 0.08 \\
\hline Acinetobacter_sp._NCu2D2 & 0.08 & 0.00 \\
\hline Salmonella_enterica & 0.00 & 0.08 \\
\hline Streptococcus_agalactiae & 0.03 & 0.06 \\
\hline Corynebacterium_sphenisci & 0.02 & 0.05 \\
\hline Corynebacterium_imitans & 0.01 & 0.05 \\
\hline Corynebacterium_segmentosum & 0.01 & 0.05 \\
\hline Corynebacterium_sp._2183 & 0.01 & 0.05 \\
\hline Klebsiella_pneumoniae & 0.01 & 0.05 \\
\hline Pseudomonas_chlororaphis & 0.01 & 0.05 \\
\hline Tessaracoccus_sp._MarseilleP5995 & 0.05 & 0.01 \\
\hline Brevibacterium_aurantiacum & 0.02 & 0.04 \\
\hline Dermabacter_vaginalis & 0.04 & 0.02 \\
\hline Acinetobacter_haemolyticus & 0.04 & 0.01 \\
\hline Acinetobacter_sp._ACNIH2 & 0.04 & 0.00 \\
\hline Acinetobacter_wuhouensis & 0.04 & 0.00 \\
\hline Staphylococcus_schweitzeri & 0.02 & 0.03 \\
\hline Acidovorax_sp._KKS102 & 0.03 & 0.00 \\
\hline
\end{tabular}


Table 1. Cont.

\begin{tabular}{ccc}
\hline Species & $\begin{array}{c}\text { Sample from } \\
\text { Patient A }\end{array}$ & $\begin{array}{c}\text { Sample from } \\
\text { Patient B }\end{array}$ \\
\hline Acinetobacter_equi & 0.03 & 0.00 \\
Acinetobacter_sp._WCHA45 & 0.03 & 0.00 \\
Acinetobacter_defluvii & 0.02 & 0.00 \\
Acinetobacter_ursingii & 0.02 & 0.00 \\
\hline
\end{tabular}

3.3. Assembly and Strain-Level Identification of Two Complete Bacterial Genomes from the Scabies-Associated Microbiome of Patient A

Strain-level identification using known strains as a reference was carried out with PanPhlAn tool and assembly was further assessed using alignment dot plots (Supplementary File, Figure S2A). Taxonomic profiling of the metagenomics reads revealed that A. baumannii (family Moraxellaceae) dominated the microbial community in Patient A. Using hierarchical clustering of the pan genome profile indicated that the strain in Patient A was related to A. baumannii J9 (NZ_CP041587.1). Mapping of the metagenome reads obtained from Patient $\mathrm{A}$ to the $A$. baumannii $\mathrm{J} 9$ genome revealed a high degree of sequence identity with only four coding genes showing sequence differences (Table 2). One of the genes encodes the virulence factor trimeric autotransporter adhesin (Ata), which matched in 2254 of 2258 amino acids. Contig assembly using metaspades and binning analysis combined with a lineage assessment of the bins using checkM indicated similarities of a metagenome-assembled genome (MAG-2) to the Moraxellaceae family with a high sequence completeness $(100 \%)$ and no contamination or strain heterogeneity $(0 \%)$. In total, the Moraxellaceae-related metagenome-assembled genome consisted of 38 contigs with 3608 predicted genes based on metagenemark. Similarity searches using BLAST to the NCBI nucleotide database confirmed that the contigs were highly similar to A. baumannii J9 as well as A. baumannii 29FS20 (NZ_CP044519.1) (Supplementary File, Table S1).

Table 2. Single nucleotide variation in the metagenomic strain using A. baumannii J9 as a reference. Ribosomal gene, tRNA genes, transposases, and prophage integrase A were excluded.

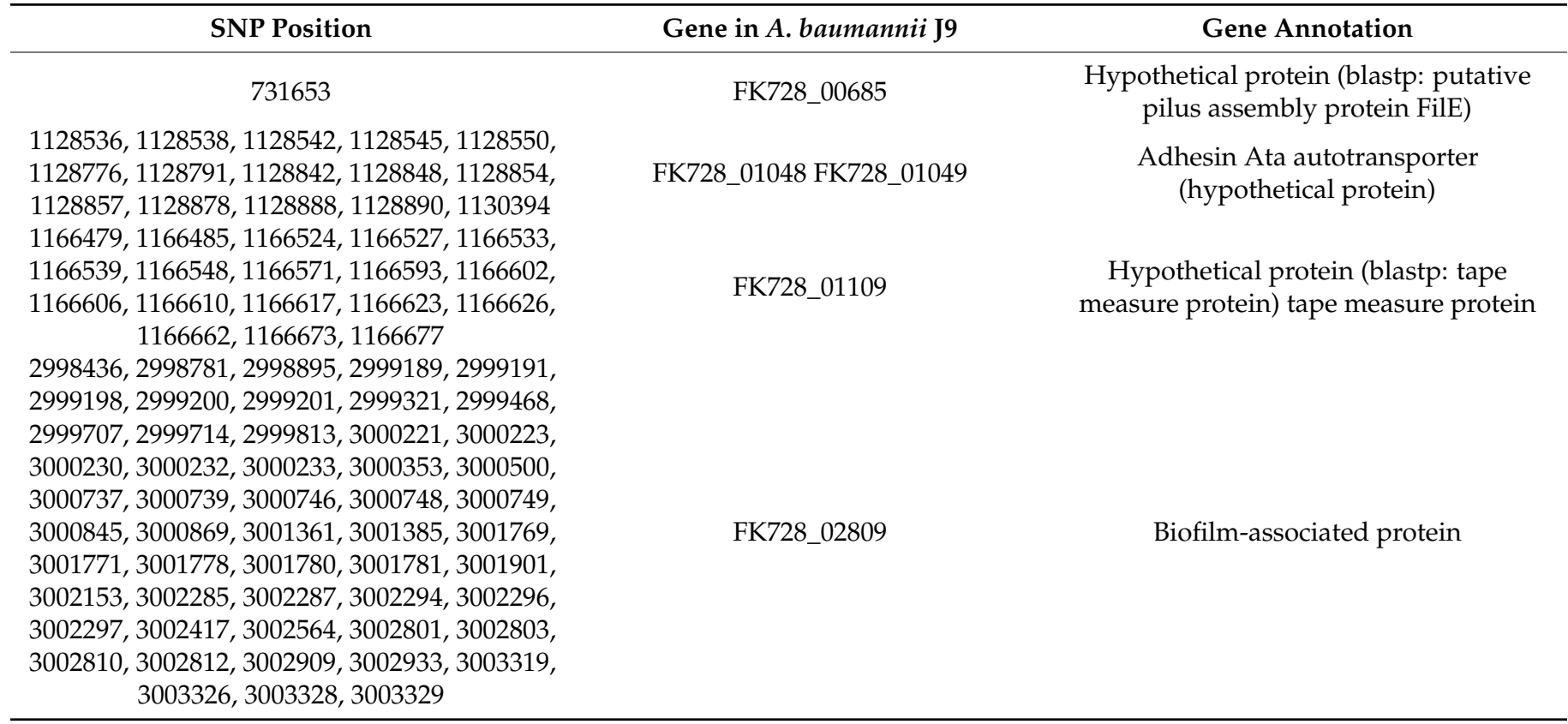

MLST analysis indicated that all marker genes were present in the metagenome MAG-2 in sample A and was classified as ST-49 or ST-128 based on Pasteur or Oxford 
marker genes schemes, respectively. A recent publication reported a similar classification of A. baumannii sequences [57].

Further metagenome binning identified a metagenome-assembled genome (MAG3) containing 149 contigs and 2003 predicted genes. Similarity analysis of the contigs indicated a close relationship to $S$. dysgalactiae and checkM predictions estimated about $97 \%$ completeness of the metagenome-assembled genome, which was confirmed using alignment dot plots (Supplementary File, Figure S2B). The MLST type 17 (ST-17) was predicted based on seven housekeeping genes (atoB, gki, gtr, murl, mutS, recP, xpt) [58]. Strain analysis of the metagenome read sequences in sample A confirmed the presence of S. dysgalactiae subsp. equisimilis, which typically encode 1878-2223 genes.

\subsection{Metagenome-Assembled Genomes in the Scabies-Associated Microbiome of Patient B}

Strain-level identification was carried out using PanPhlAn tool and genome coverage was assessed using alignment dot plots (Supplementary File, Figure S2C,D). Binning the metagenomic contigs resulted in a metagenome-assembled genome (MAG-1) consisting of 114 contigs and encoding 2455 genes. Quality assessment of this metagenome-assembled genome using checkM indicated a $97 \%$ genome completeness and $0.8 \%$ contamination based on markers identified in the genus Staphylococcus. Most contig sequences within this bin matched the genomes of $S$. aureus subsp. aureus MW2 (BA000033.2, 2632 genes) and S. aureus strain MSSA476 (BX571857.1, 2598 genes). Using SCCmecFinder, two SCCmec cassettes were identified, which were predicted as SCCmec_type_I (1B) (gb | AB033763.2) and SCCmec_type_IV (2B) (gb | AB063172.2) (Table 3). In addition, the MLST type based on seven housekeeping genes ( $\operatorname{arcC}, \operatorname{aroE}, g l p F, g m k, p t a, t p i, y q i L)$ was type 1 (ST-1) and spa Type t127 [59].

Table 3. SCCmec cassettes genes identified in the metagenome-assembled Staphylococcus aureus genome. SCCmec, Staphylococcal Cassette Chromosome mec; HSP, high scoring pair.

\begin{tabular}{ccccc}
\hline SCCmec Genes & \% Identity & Query/HSP Length & Contig & Position in Contig \\
\hline ccrA2:7:81108:AB096217 & 100 & $1350 / 1350$ & NODE_170_length_13084_cov_4.268171 & $10888 . .12237$ \\
ccrB1:1:COL:CP000046 & 92.31 & $1626 / 1625$ & NODE_48_length_30375_cov_4.414413 & $13661 . .15286$ \\
ccrA1:1:COL:CP000046 & 94.37 & $1350 / 1350$ & NODE_48_length_30375_cov_4.414413 & $15308 . .16657$ \\
subtype- & 100 & $1491 / 1491$ & NODE_48_length_30375_cov_4.414413 & $184 . .1674$ \\
IVa(2B):1:CA05:AB063172 & 100 & $2010 / 2010$ & NODE_170_length_13084_cov_4.268171 & $2473 . .4482$ \\
mecA:12:AB505628 & 100 & $987 / 987$ & NODE_170_length_13084_cov_4.268171 & $4579 . .5565$ \\
dmecR1:1:AB033763 & 100 & $1843 / 1843$ & NODE_170_length_13084_cov_4.268171 & $5554 . .7396$ \\
IS1272:3:AM292304 & $1650 / 1650$ & NODE_170_length_13084_cov_4.268171 & $9238 . .10887$ \\
ccrB2:9:JCSC4469:AB097677 & 99.88 & & &
\end{tabular}

A bin of 306 contigs encoding 3456 genes in sample B was similar to P. mirabilis BB2000 (CP004022.1, 3455 genes) and P. mirabilis strain AOUC-001 (CP015347, 3853 genes). Analysis with checkM revealed $93 \%$ completeness and 1\% contamination to the class Proteobacteria.

\subsection{Identification of Bacterial Virulence Factors Genes}

\subsubsection{Acinetobacter}

One major factor contributing to A. baumannii species virulence is their capacity to form biofilm. We investigated the presence of biofilm-related genes using the VFDB and NCBI protein database. We identified several virulence factors genes, the outer membrane protein A OmpA, chaperon-usher pilus CsuE, component system BfmRS, tyrosine-protein kinase $p t k, p g a B$, poly- $-(1,6)-\mathrm{N}$-acetyl glucosamine $P N A G$, extracellular exopolysaccharide EPS and partial biofilm-associated protein Bap. No contigs and reads were matching the biofilm formation genes $\operatorname{csg} A$, $\mathrm{kps} M I I$ or fimH. We identified both integrase int $A-1$ and int $A$-2 genes. The biofilm-associated protein (Bap) was predicted on the terminal end of two contigs. Bap is a large cell surface protein, which is critical for cell-cell interaction and biofilm formation [60]. The porin OmpA is involved in attachment and invasion to the 
host epithelial cells, serum resistance, biofilm formation and persistence and induction of apoptosis [60]. The Csu pilus initiates biofilm formation on abiotic surfaces [60]. The two-component system bfmRS regulates the expression of the csu gene.

\subsubsection{Streptococcus}

Major streptococcal virulence factors were identified which are typical and essential for these invasive pathogens [6]. In the skin metagenome from sample A, S. dysgalactiae genes $\operatorname{lmb}$ and $g f b A$ (partial) coding for adhesins, which are virulence factors related to adherence and internalisation to host cells, were present [61]. One gene matched and completely covered the emm (M-protein) from S. dysgalactiae (WP_148848339) with an identity of $98.85 \%$. We did not identify the complete emm (M-protein) of S. pyogenes in the skin-assembled metagenome from sample A, and only 37 reads mapped to the reference gene M-protein of S. pyogenes. Given the low read counts, no further analysis was carried out. Similarly, genes coding for streptococcal secreted factors such as Streptolysins $S$ and $\mathrm{O}(S L S, S L O)$ or streptococcal exotoxins B (SpeB) were not identified with certainty in the assembled contigs and reads data.

\subsubsection{Staphylococcus}

The Staphylococcus metagenome-assembled genome encoded various virulence factors including toxins (haemolysin, enterotoxins), enzymes relevant for adherence and colonization of the bacterium (clumping factor, fibronectin binding proteins), immune evasion (capsule) and iron uptake [62]. Although at a low read coverage of two reads per position, about $86 \%$ of the reference gene for the $\operatorname{IgG}$ binding protein A precursor $(S p A)$ from $S$. aureus was covered by the dataset from sample B. This gene encodes the bacteria surface protein SPA that binds to the $\mathrm{F}_{\mathrm{C}}$ region of $\operatorname{IgG}$ which disrupts opsonisation and phagocytosis [62]. SPA can also increase pro-inflammatory cytokine levels and was associated with a reduced skin barrier function and increased severity of skin lesion in an atopic dermatitis mouse model and in human studies [63,64]. The sequence of the gene staphylococcal es $x A$ was completely recovered in the data obtained from sample B. This gene is coding for the protein EsxA, a virulence factor present in S. aureus strains recovered from lesions of psoriatic patients but absent from strains found at unaffected sites [65].

\subsection{Antibiotic Resistance}

The metagenomes harboured various antibiotic resistance genes including mgrA, mecA, (methicillin-resistance), fusC (fusidic acid), tet38 (tetracycline), mepA (tetracycline), ErmC (macrolide, lincosamide, streptogramin B) from Staphylococcus sp., tetJ (tatracycline) from Proteus sp. and ADC-3 (cephalosporin), ADC-80 (cephalosporin), ADC-6 (cephalosporin), ADC-68 (carbapenem) and adeIJKLMN (multidrug classes), OXA-98 (penam, cephalosporin), abeS (macrolide, aminocoumarin antibiotic), adeFGH (tetracycline, fluoroquinolone antibiotic), ANT( $\left.3^{\prime \prime}\right)$-lia (aminoglycoside antibiotic) from Acinetobacter sp.

A betalactamase gene was identified in the metagenome-assembled genome of $A$. baumannii. Several antibiotic resistance proteins were identified in the metagenome-assembled genome of $S$. aureus using the CARD database including the antibiotic efflux pumps ArlR and MgrA, fusidic acid inactivation enzyme FusC, MecA (methicillin resistant PBP2), tetracycline resistant protein (tet38) and multidrug export protein MepA and its repressor mepR (Table 4). Partial sequences of the arlS protein, that forms a complex with ArlR, and the signal protein mecR1, which mediates the gene regulation for the methicillin resistance, were predicted. 
Table 4. List of genes with hits to the CARD database based on similarity searches.

\begin{tabular}{ccccc}
\hline Gene & Reference & Annotation & Identity (\%) & Reference Covered (\%) \\
\hline gene_id_37 & WP_001283444.1 & mgrA & 100 & 100 \\
gene_id_770 & YP_001440920.1 & mepR & 100 & 92.80576 \\
gene_id_1437 & AAV80464.1 & tet(38) & 99.556 & 100 \\
gene_id_1460 & WP_001033157 & fusC & 100 & 100 \\
gene_id_2147 & AGC51118.1 & mecA 99.701 & 668 & 100 \\
gene_id_2148 & YP_001245420.1 & mecR1 & 100 & 41.88034 \\
gene_id_2332 & WP_000192137.1 & arlR & 100 & 100 \\
gene_id_2333 & YP_499945.1 & arlS 100.000 & 383 & 84.92239 \\
\hline
\end{tabular}

\subsection{Degradome}

Using the MEROPS database as a reference, genes with proteolytic functions were identified in the above outlined microbial genomes. In the dataset obtained from the sample from Patient A, genes encoding the intramembrane protease rseP, which transmits the outer membrane environmental stress for example due to antibiotics, and S-formylglutathione hydrolase FrmB for detoxification of xenobiotic molecules in A. baumannii were found [66]. In the dataset collected from sample B, predominantly proteases from $S$. aureus were identified including collagenases, the beta-lactamase regulator BlaR1, class $\mathrm{C}$ beta-lactamase, the extracellular adherence protein homolog EapH2 and a caseinolytic protease $(\mathrm{Clp})$ involved in the degradation of damaged proteins. Furthermore, the sample from Patient B metagenome encoded pitrilysin, which degrades small peptides and contributes for instance to the pathogenicity of Vibrio vulnificus through the proteolytic degradation of insulin [67], and mirabilysin from P. mirabilis, which is an IgA-degrading metalloprotease [68].

\subsection{Metabolic Pathways Analysis Using KEGG Pathways}

Mapping of the genes and contigs revealed a good representation of three KEGG pathways, i.e., 'Bacterial invasion', 'Staphylococcus infection' and 'Cationic antimicrobial peptides' (Supplementary File, Figure S3). Genes corresponding to the 'Bacterial invasion' pathway were identified in the metagenomes and were essentially coding for adhesin proteins and fibronectin-binding proteins (e.g., FnBPA, FnBPB, Pfb or Sfb1). Pathogenic bacteria such as Staphylococci and Streptococci are able to adhere to human skin fibroblasts and to invade epithelial cells using a zipper model mechanism. These Gram-positive bacteria express adhesin proteins on their surfaces that interact with extracellular matrix components of the host such as fibronectin, resulting in close apposition of the epithelial cellular membrane around the entering bacteria [69-71] (Supplementary File, Figure S3). Genes from the pathway 'Staphylococcus infection' were identified in both samples from Patient A and Patient B. Most genes were coding for various virulence factors including: enzymes relevant for adherence and colonisation of the bacterium (e.g., clumping factor ClfB, IsdA adhesin, surface protein G SasG, extracellular fibrinogen-binding protein $\mathrm{Efb}$ ), immune modulating proteins inhibiting complement activation (e.g., staphylococcal complement inhibitor SCIN), opsonisation (e.g., extracellular complement binding proteins Ecb) or neutrophil chemotaxis (e.g., chemotaxis inhibiting protein CHIPS), proteins modulating immune evasion (e.g., IgG binding protein A SpA and the second immunoglobulin-binding protein $\mathrm{Sbi}$ ), modulating the sensitivity to cationic antimicrobial peptides (such as defensin) by increasing the positive net charge of its cytoplasmic membrane (e.g., VraF, VraG, Dlt, $\mathrm{MprF}$ ), and expression of toxins (e.g., haemolysins and enterotoxins) and superantigens [62] (Supplementary File, Figure S3). The third pathway that was identified is the 'Cationic antimicrobial peptides' pathway. Cationic antimicrobial peptides (CAMPs) are key components of the innate immune response playing an important role in host defence against microbial infection, particularly into the skin. CAMPs are able to weaken the integrity of the bacterial inner and outer membranes and thereby to kill bacterial cells. Therefore, pathogenic bacteria have developed numerous mechanisms to evade the activity of CAMPs. 
In the Staphylococcus metagenome-assembled genome, various resistance mechanisms to CAMPs were found, comprising the capacity to sense the presence of CAMPs (e.g., GraRS), to decrease the attraction or to repulse them via alteration of cell wall and membrane surface charges (e.g., MprF which modifies phosphatidylglycerol with lysyl residues adding positively charged lysine molecules within the $S$. aureus cell membrane and DltABCD operons that D-alanylate teichoic acids and neutralize the negative net charge of the staphylococcal cell wall), to export them with membrane efflux pumps (e.g., VraFG), to degrade them with secreted proteases (e.g., aureolysin Aur, staphylokinase) and finally to neutralize them by sequestration and external trapping mechanisms [72] (Supplementary File, Figure S3).

3.9. A. baumannii, S. pyogenes, S. dysgalactiae, and S. aureus Are Present Scabies Mite Gut and in Surrounding Human Skin

We were able to localize A. baumannii, S. pyogenes, S. dysgalactiae and S. aureus within the scabies mites and in the surrounding skin using skin sections and probing with bacteriaspecific antibodies. Within the scabies mite, the bacteria were present in the mite digestive system (Figure 4, Panel 1C-E and 2C-E) and were released into the epidermal burrows, with the mite faeces (Figure 4, Panel 3C-E and 4C-E). We did not observe any bacteria within intact S. scabiei eggs; hence, we postulate that freshly hatched larvae take up the bacteria when feeding.

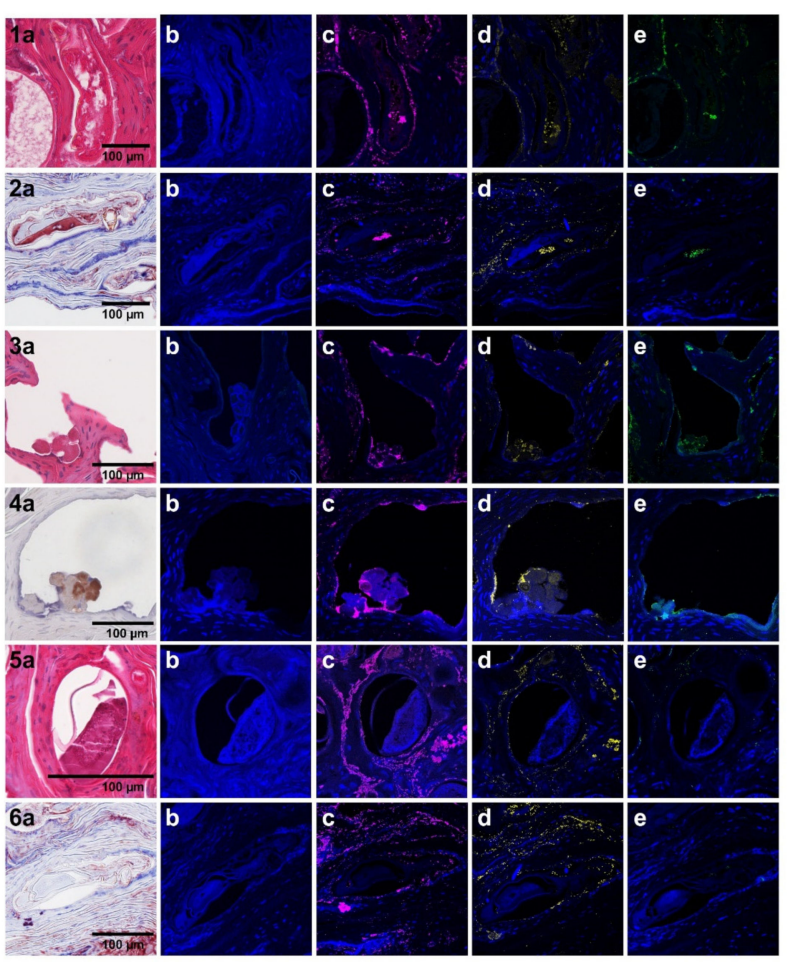

Figure 4. Immunohistological localisation of A. baumannii, S. pyogenes, S. dysgalactiae and S. aureus in S. scabiei var. hominis-infested epidermal tissue by confocal microscopy. Series 1-6 are serial histological sections of scabies mite-infested human skin showing localised bacteria. Series 1 and 2 feature adult $S$. scabiei var. hominis mites within epidermal burrows; series 3 and 4 show mite faecal pellets; series 5 depicts a laid egg, and series 6 an unlaid egg within an adult female mite. Adjacent section of each series were H\&E-stained (1a, 3a, and $\mathbf{5 a}$ ) or probed with anti-human IgG as a mite gut marker (2a, 4a, and 6a). In these sections, red staining indicates antibody binding to protein. Sections in column (b) were probed with pre-immune mouse sera (negative control). Sections in columns (c-e) were probed with antibodies specific for S. aureus, A. baumannii, and S. pyogenes/S. dysgalactiae, respectively. The scale bar is $100 \mu \mathrm{m}$. 


\section{Discussion}

In this study, a metagenome sequencing approach on the Hi-Seq Illumina platform was employed to investigate the microbial community accompanying severe scabies infection (i.e., crusted scabies), in two human patients residing in northern Australia. By picking the parasites from unwashed and untreated skin samples, the microbial communities residing internally within the mite, and externally on the mite surface and within the skin microenvironment were captured. The microbiome analysis confirmed the presence of pathogenic bacteria of the genera Streptococcus and Staphylococcus within scabies-infested skin, and identified further associated pathogens such as A. baumannii, Pseudomonas aeruginosa, and Proteus mirabilis.

From the sample of Patient A, we could assemble two bacterial genomes, classified as A. baumannii and S. dysgalactiae subsp. equisimilis. A. baumannii is a Gram-negative bacterium that is ubiquitous in nature and a commensal of human skin, present in $20-25 \%$ of humans [73]. The bacterium can be pathogenic as it adheres to and invades human host cells causing bacteraemia, wound infections, pneumonia, endocarditis or meningitis [74-79]. A. baumannii has been identified as an important nosocomial pathogen due to its ability to form biofilms, modulate host cell signalling, induce apoptosis, develop serum resistance, and perform immune evasion [80]. Interestingly, genes that varied between the recently sequenced $A$. baumannii genome $\mathrm{J} 9$ and the isolate identified here are relevant in the process of attachment and invasion of human host cells. The autotransporter adhesion (Ata) protein mediates adhesion to the extracellular matrix proteins and virulence in a murine pneumonia model [81]. Experiments with an Ata knockout strain have indicated that A. baumannii induces host cell secretion of pro-inflammatory cytokines IL-8 during early and IL-6 during later infection stages and monocytes recruitment [81]. In some pathogens, motility organelles contribute to biofilm formation and host cell adherence. The type IV pili (T4P) is a bacterial appendage ubiquitous within A. baumannii and composed of a cytoplasmic AAA + ATPase (PilB), an integral membrane protein (PilC) and at least two pilins (PilA). A. baumannii was declared the number one priority pathogen for research by the World Health Organisation due to its pathogenicity related to a growing multidrug antibiotic resistance [82]. A mechanism to develop resistance to host immune responses is by prophage-mediated gene transfer. Herein, we have identified two integrases and several transposases of the family IS3 and IS5. The genome also carried virulence factors involved in the uptake of iron and other micronutrients, motility, production of cytotoxic and protection factors, biofilm formation and adhesion to and invasion into human host cells.

Group C and G Streptococci such as S. dysgalactiae subsp. equisimilis are phylogenetically very similar to $S$. pyogenes. They can be skin commensals or pathogens inducing similar spectrum of illness as caused by GAS, such as wound infections, erysipelas and cellulitis. S. dysgalactiae subsp. equisimilis is also reported to be associated with life-threatening necrotizing fasciitis and streptococcal toxic shock syndrome [83]. Notably, very low level of GAS is present in the sample from Patient $\mathrm{A}$, which contains a high abundance of $S$. dysgalactiae subsp. Equisimilis. GAS and S. dysgalactiae subsp. Equisimilis are phylogenetically close, compete for the same resources and cause a similar disease spectrum in humans. S. dysgalatiae subsp. Equisimilis have been reported to produce antimicrobial proteins specifically active against GAS [84] and this may explain the low abundance of GAS in this case.

The data retrieved from the sample from Patient B was dominated by metagenomeassembled genomes related to $S$. aureus. The bacterium $S$. aureus is both a frequent commensal of the skin and a common human pathogen, causing skin and soft tissue infections, bacteraemia and osteomyelitis $[85,86]$. S. aureus species are characterised by their high resistance against common antibiotics and are prominent pathogens causing persistently high mortality worldwide. The most important laboratory documented resistance is to methicillin, an anti-staphylococcal penicillin that is a surrogate used in laboratory testing for flucloxacillin resistance. Methicillin resistance in S. aureus (MRSA) is mediated by the mecA gene, which is embedded in a mobile genetic element termed staphylococcal 
cassette chromosome mec (SCCmec). SCCmec also includes site-specific recombinase genes (ccrA, crrB) enabling the mobility of the region and is inserted within the orf $\mathrm{X}$ gene (RNA methyltransferase) [86]. Infection due to community-associated strains of MRSA was first recognized in Australia in people from remote Indigenous communities of northern Australia [87]. They now have a very high prevalence of MRSA infections, correlated with measures of remoteness and socioeconomic disadvantage. One of the $S$. aureus strains in the sample from Patient B was identified as spa type t127, sequence Type ST-1. This strain, which is methicillin-resistant, has been frequently isolated in pigs in some countries, mostly in Europe, and is considered as the most widespread methicillin-resistant livestockassociated S. aureus [88]. Mofiz et al. [37] compared the mite mitochondrial genome data from pig mites (S. scabiei var. suis) to mites from humans (S. scabiei var. hominis). In a Single Nucleotide Polymorphism (SNP) analysis of mite gDNA from the same two human samples under investigation here (Patient $A$ and $B$ ) and from four pig samples, the authors identified 16 mtDNA haplotypes in total, falling into two broad clades and six distinct haplogroups [37]. Three pig mite haplogroups (seven haplotypes) and three human mite haplogroups (four haplotypes) were identified. In a phylogenetic tree, all pig mite haplogroups clustered closely. Among the three human mite haplogroups, two grouped together, with two Patient A human mite haplotypes (H1_A and H2_A) being essentially clonal, and Patient B haplotype H2_B being very close to these. Between these human and pig mite haplotypes, a sequence divergence of about 600 SNPs was observed. The fourth human mite haplotype (H1_B_REF) however, was very close to the pig mite haplotypes, with only about 80 SNPs difference [37]. This data indicates that some human and pig mites may be very closely related. We could speculate that Patient B may have lived around livestock animals such as pigs and that they could have shared microorganisms. If so, the S. aureus strain from Patient B may be zoonotically acquired, possibly from pigs. Indeed, scabies mites could have acted as a vector for transmission of this pathogenic bacterium.

We also found evidence of $P$. mirabilis and P. aeruginosa. Both microorganisms are Gram-negative, rod-shaped bacteria widely distributed in soil and water. P. mirabilis is most frequently involved in infections of the urinary tract [89], and rarely found in the skin, whereas P. aeruginosa can be involved in skin infections, for example after burn injuries or any cause of rupture of the skin barrier [90].

It is generally accepted that microbiota play an important role in protecting the host from pathogens. Resident microbiota perform this protective function in a number of ways, such as colonisation resistance and modulating the host immune system. Colonisation resistance involves limiting the nutrients and space for initial colonisation of potential pathogens. In addition, the microbiota may modulate the types of immune reaction or secretion of antimicrobial peptides by the host against certain groups of microbes, thereby maintaining homeostasis. Perturbation of the resident skin microbiota (i.e., dysbiosis) during a scabies infestation was demonstrated in vivo in a porcine experimental model [87]. With the onset of scabies mite infection, the healthy resident skin microbiota changed rapidly and dramatically. The main observation was a general reduction in the microbial diversity and a massive rise of pathogenic Staphylococcal species (foremost $S$. chromogenes) [91]. These bacteria are well-known pathogens in pigs, however in healthy porcine skin they are kept at low numbers. We propose that, when epidermal barrier and microbial composition are disrupted, opportunistic pathogens may switch on their virulent traits [92]. At the same time, the burrowing scabies mites release molecules into the skin that interfere with the host innate immune response [31-34], promoting the growth of opportunistic bacteria [28-30,34].

In this study, we sequenced both the mite external (i.e., epidermal microbiota associated with the mite) and the mite internal (intestinal) microbiota. We therefore cannot determine here if some of the identified pathogenic bacteria were originally host skin bacteria, which were amplified due to mite infection, or if the scabies mites may even act as a vector for transmission of some of these pathogenic bacteria. We were limited to investigating samples from crusts from scabies patients and were not in the position to 
generate a patient-specific 'healthy skin' control dataset. Consequently, we are not able to establish whether the opportunistic pathogens were present as a part of the normal skin flora. Arthropods have their own, distinct microbiota, which play a role in their biology and pathogenicity. Often arthropod microbiota include symbionts, which may provide the host with specific essential nutrients, defence against external factors or which may manipulate reproduction. Disruption or removal of the internal microbiota and endosymbionts in arthropods has been reported to reduce survival, fecundity and growth of arthropods without inhibiting feeding [93-95]. Aiming to investigate the internal microbiota of scabies mites, metagenome analysis of pig mites (S. scabiei var. suis) has detected the presence of opportunistic pathogen, Klebsiella pneumonia and a probable bacterial symbiont, namely Streptomyces [96]. The findings were confirmed histologically with FISH analysis [96]. This study highlighted that the scabies mite indeed may act as a vector for transfer of opportunistic pathogens. Future exploration into the internal microbiome will give a better understanding of the scabies mite biology.

Bouvresse et al. described the presence of A. baumannii in human head lice (Pediculus humanus capitis), present in the hair of elementary schoolchildren in Paris, France. Using molecular detection methods, the authors were able to detect A. baumannii DNA in 33\% of the target population (95 positives samples out of 288, 74 schools from 2008 to 2009) [97]. Similar findings were reported from Ethiopia, Thailand, Algeria, Malaysia, and Gabon [98-102]. In addition, the bacterium was also present in body lice (Pediculus humanus morphotype corporis) [103]. It will require further studies to clarify whether arthropod hosts, insects or acari, can act as hidden environmental reservoirs for bacteria and whether they can promote the spread of the bacteria between individuals in host communities.

This study is the first to describe the composition of the skin microbial community that accompanies severe scabies infection in humans. We emphasize that this exploratory pilot study provides an exemplary (not representative) picture. While limited to samples from only two patients, the data unveiled the presence of numerous pathogenic bacteria present in the mite-infested skin. This microbiota harbours complex functional capabilities that may be relevant to their invasion of the human host and to enhancing their pathogenicity. Based on these crucial fundamental findings, we are currently conducting a larger ampliconbased study including patients from four different countries with different socio-economic features and climates, to investigate the impact of scabies infection on the associated skin microbiota.

Supplementary Materials: The following are available online at https:/ / www.mdpi.com/article/ $10.3390 /$ microorganisms $9050907 /$ s1. Figure S1: Testing of the specificity of primary antibodies, Figure S2: Alignment dot plots, Figure S3. Mapping of the genes and contigs to KEGG pathways, Table S1: The 38 contigs of the metagenome-assembled genome MAG-2 blast to A. baumannii genomes in the NCBI nucleotide database.

Author Contributions: C.B., M.Z., P.M.S., and K.F. conceived and planned the experiments; C.B., M.Z., S.T., P.M.S., A.T.P., D.H., and K.F. performed the experiments and analysed the data; K.S.S., O.C., B.J.C., and K.F. supervised the experiments and the analysis of the data; C.B., M.Z., S.T., P.M.S., and K.F. wrote the manuscript; C.B., M.Z., S.T., P.M.S., A.T.P., K.S.S., D.H., O.C., B.J.C. and K.F. edited and contributed to the final version of the manuscript. All authors have read and agreed to the published version of the manuscript.

Funding: C.B. was supported by a PhD scholarship from the French Society of Dermatology. K.F. is supported by an Australian National Health and Medical Research Council (NHMRC) Senior Research Fellowship (APP1154805). The study was funded by the Australian NHMRC Project Grant (APP1098804). The funders of the study had no role in study design, data collection, data analysis, data interpretation, or writing of the report of this study.

Institutional Review Board Statement: The study was conducted according to the guidelines of the Declaration of Helsinki, and approved by the Human Research Ethics Committee of the Northern Territory Department of Health and Menzies School of Health Research (approval 13-2027).

Informed Consent Statement: Informed consent was obtained from all subjects involved in the study. 
Data Availability Statement: The data presented in this study are available on request from the corresponding author or Matha Zakrzewski (Martha.Zakrzewski@qimrberghofer.edu.au).

Acknowledgments: We would like to gratefully acknowledge both patients that agreed to participate in the study. We thankfully acknowledge the expertise and assistance with IHC and confocal imaging of Tam Hong Nguyen, Nigel Waterhouse, Clay Winterford in the Histology Services of QIMR Berghofer MRI, Mark Blaskovich from the Institute for Molecular Biosciences at the University of Queensland for his kind donation of the A. baumannii ATC19606, Alison Carey at Institute of Health Biomedical Innovation at Queensland University of Technology for donation of S. agalactiae 18RS21 Type II and David J. McMillan for his kind donation of the S. dysgalactiae NS3396 emm-type STG-480. We gratefully acknowledge the expertise and assistance with eukaryotic species of Françoise Botterel, Department of Microbiology, Parasitology and Mycology, APHP, Hôpital Henri-Mondor, Université Paris-Est, Créteil, France.

Conflicts of Interest: Charlotte Bernigaud and Olivier Chosidow act as unpaid scientific advisors for Medicines Development for Global Health. No other competing interests were declared.

\section{References}

1. Chosidow, O. Scabies and pediculosis. Lancet 2000, 355, 819-826. [CrossRef]

2. Chosidow, O. Clinical practices. Scabies. N. Engl. J. Med. 2006, 354, 1718-1727. [CrossRef]

3. Engelman, D.; Cantey, P.T.; Marks, M.; Solomon, A.W.; Chang, A.Y.; Chosidow, O.; Enbiale, W.; Engels, D.; Hay, R.J.; Hendrickx, D.; et al. The public health control of scabies: Priorities for research and action. Lancet 2019, 394, 81-92. [CrossRef]

4. Karimkhani, C.; Colombara, D.V.; Drucker, A.M.; A Norton, S.; Hay, R.; Engelman, D.; Steer, A.; Whitfeld, M.; Naghavi, M.; Dellavalle, R.P. The global burden of scabies: A cross-sectional analysis from the Global Burden of Disease Study 2015. Lancet Infect. Dis. 2017, 17, 1247-1254. [CrossRef]

5. Romani, L.; Steer, A.C.; Whitfeld, M.J.; Kaldor, J.M. Prevalence of scabies and impetigo worldwide: A systematic review. Lancet Infect. Dis. 2015, 15, 960-967. [CrossRef]

6. Wong, L.-C.; Amega, B.; Barker, R.; Connors, C.; Dulla, M.E.; Ninnal, A.; Cumaiyi, M.M.; Kolumboort, L.; Currie, B.J. Factors supporting sustainability of a community-based scabies control program. Australas. J. Dermatol. 2002, 43, 274-277. [CrossRef]

7. Chosidow, O.; Fuller, L.C. Scratching the itch: Is scabies a truly neglected disease? Lancet Infect. Dis. 2017, 17, 1220-1221. [CrossRef]

8. Nakatsuji, T.; Chiang, H.-I.; Jiang, S.B.; Nagarajan, H.; Zengler, K.; Gallo, R.L. The microbiome extends to subepidermal compartments of normal skin. Nat. Commun. 2013, 4, 1431. [CrossRef]

9. Grice, E.A.; Kong, H.H.; Conlan, S.; Deming, C.B.; Davis, J.; Young, A.C.; Bouffard, G.G.; Blakesley, R.W.; Murray, P.R.; Green, E.D.; et al. Topographical and Temporal Diversity of the Human Skin Microbiome. Science 2009, 324, 1190-1192. [CrossRef]

10. Bowen, A.C.; Mahé, A.; Hay, R.J.; Andrews, R.M.; Steer, A.C.; Tong, S.Y.C.; Carapetis, J.R. The Global Epidemiology of Impetigo: A Systematic Review of the Population Prevalence of Impetigo and Pyoderma. PLoS ONE 2015, 10, e0136789. [CrossRef]

11. Lynar, S.; Currie, B.J.; Baird, R. Scabies and mortality. Lancet Infect. Dis. 2017, 17, 1234. [CrossRef]

12. Carapetis, J.R.; Steer, A.C.; Mulholland, E.K.; Weber, M. The global burden of group A streptococcal diseases. Lancet Infect. Dis. 2005, 5, 685-694. [CrossRef]

13. Boyd, R.N.; Patel, M.; Currie, B.J.; Holt, D.C.; Harris, T.B.; Krause, V. High burden of invasive group A streptococcal disease in the Northern Territory of Australia. Epidemiol. Infect. 2016, 144, 1018-1027. [CrossRef] [PubMed]

14. Ralph, A.P.; Carapetis, J.R. Group a streptococcal diseases and their global burden. Curr. Top. Microbiol. Immunol. 2013, 368, 1-27. [PubMed]

15. Watkins, D.A.; Johnson, C.O.; Colquhoun, S.M.; Karthikeyan, G.; Beaton, A.; Bukhman, G.; Forouzanfar, M.H.; Longenecker, C.T.; Mayosi, B.M.; Mensah, G.A.; et al. Global, Regional, and National Burden of Rheumatic Heart Disease, 1990-2015. N. Engl. J. Med. 2017, 377, 713-722. [CrossRef]

16. Marijon, E.; Celermajer, D.S.; Jouven, X. Rheumatic Heart Disease-An Iceberg in Tropical Waters. N. Engl. J. Med. 2017, 377, 780-781. [CrossRef]

17. Roberts, L.; Huffam, S.; Walton, S.; Currie, B. Crusted scabies: Clinical and immunological findings in seventy-eight patients and a review of the literature. J. Infect. 2005, 50, 375-381. [CrossRef] [PubMed]

18. Hasan, T.; Krause, V.L.; James, C.; Currie, B.J. Crusted scabies; a 2-year prospective study from the Northern Territory of Australia. PLoS Negl. Trop. Dis. 2020, 14, e0008994. [CrossRef] [PubMed]

19. Steer, A.C.; Jenney, A.W.J.; Kado, J.; Batzloff, M.R.; La Vincente, S.; Waqatakirewa, L.; Mulholland, E.K.; Carapetis, J.R. High Burden of Impetigo and Scabies in a Tropical Country. PLoS Negl. Trop. Dis. 2009, 3, e467. [CrossRef]

20. McMeniman, E.; Holden, L.; Kearns, T.; Clucas, D.B.; Carapetis, J.R.; Currie, B.J.; Connors, C.; Andrews, R.M. Skin disease in the first two years of life in Aboriginal children in East Arnhem Land. Australas. J. Dermatol. 2011, 52, 270-273. [CrossRef]

21. Whitehall, J.; Kuzulugil, D.; Sheldrick, K.; Wood, A. Burden of paediatric pyoderma and scabies in North West Queensland. J. Paediatr. Child Health 2013, 49, 141-143. [CrossRef] 
22. Hay, R.J.; Steer, A.C.; Chosidow, O.; Currie, B.J. Scabies: A suitable case for a global control initiative. Curr. Opin. Infect. Dis. 2013, 26, 107-109. [CrossRef]

23. Gear, R.J.; Carter, J.C.; Carapetis, J.R.; Baird, R.; Davis, J.S. Changes in the clinical and epidemiological features of group A streptococcal bacteraemia in Australia's Northern Territory. Trop. Med. Int. Health 2015, 20, 40-47. [CrossRef] [PubMed]

24. Lawrence, G.; Leafasia, J.; Sheridan, J.; Hills, S.; Wate, J.; Wate, C.; Montgomery, J.; Pandeya, N.; Purdie, D. Control of scabies, skin sores and haematuria in children in the Solomon Islands: Another role for ivermectin. Bull. World Health Org. $2005,83,34-42$.

25. McDonald, M.; Currie, B.J.; Carapetis, J.R. Acute rheumatic fever: A chink in the chain that links the heart to the throat? Lancet Infect. Dis. 2004, 4, 240-245. [CrossRef]

26. Hoy, W.E.; White, A.V.; Dowling, A.; Sharma, S.K.; Bloomfield, H.; Tipiloura, B.T.; Swanson, C.E.; Mathews, J.D.; McCredie, D.A. Post-streptococcal glomerulonephritis is a strong risk factor for chronic kidney disease in later life. Kidney Int. 2012, 81, 1026-1032. [CrossRef] [PubMed]

27. Swe, P.M.; Reynolds, S.L.; Fischer, K. Parasitic scabies mites and associated bacteria joining forces against host complement defence. Parasit. Immunol. 2014, 36, 585-593. [CrossRef] [PubMed]

28. Swe, P.M.; Christian, L.D.; Lu, H.C.; Sriprakash, K.S.; Fischer, K. Complement inhibition by Sarcoptes scabiei protects Streptococcus pyogenes-An in vitro study to unravel the molecular mechanisms behind the poorly understood predilection of $S$. pyogenes to infect mite-induced skin lesions. PLoS Negl. Trop. Dis. 2017, 11, e0005437. [CrossRef]

29. Swe, P.M.; Fischer, K. A Scabies Mite Serpin Interferes with Complement-Mediated Neutrophil Functions and Promotes Staphylococcal Growth. PLoS Negl. Trop. Dis. 2014, 8, e2928. [CrossRef]

30. Mika, A.; Reynolds, S.L.; Pickering, D.; McMillan, D.; Sriprakash, K.S.; Kemp, D.J.; Fischer, K. Complement Inhibitors from Scabies Mites Promote Streptococcal Growth-A Novel Mechanism in Infected Epidermis? PLoS Negl. Trop. Dis. 2012, 6, e1563. [CrossRef]

31. Fischer, K.; Langendorf, C.G.; Irving, J.A.; Reynolds, S.; Willis, C.; Beckham, S.; Law, R.H.; Yang, S.; Bashtannyk-Puhalovich, T.A.; McGowan, S.; et al. Structural Mechanisms of Inactivation in Scabies Mite Serine Protease Paralogues. J. Mol. Biol. 2009, 390, 635-645. [CrossRef]

32. Bergström, F.C.; Reynolds, S.; Johnstone, M.; Pike, R.N.; Buckle, A.M.; Kemp, D.J.; Fischer, K.; Blom, A.M. Scabies Mite Inactivated Serine Protease Paralogs Inhibit the Human Complement System. J. Immunol. 2009, 182, 7809-7817. [CrossRef]

33. Mika, A.; Reynolds, S.L.; Mohlin, F.C.; Willis, C.; Swe, P.M.; Pickering, D.A.; Halilovic, V.; Wijeyewickrema, L.C.; Pike, R.N.; Blom, A.M.; et al. Novel scabies mite serpins inhibit the three pathways of the human complement system. PLoS ONE 2012, 7, e40489. [CrossRef]

34. Reynolds, S.L.; Pike, R.N.; Mika, A.; Blom, A.M.; Hofmann, A.; Wijeyewickrema, L.C.; Kemp, D.; Fischer, K. Scabies Mite Inactive Serine Proteases Are Potent Inhibitors of the Human Complement Lectin Pathway. PLoS Negl. Trop. Dis. 2014, 8, e2872. [CrossRef]

35. Currie, B.J.; Harumal, P.; McKinnon, M.; Walton, S.F. First Documentation of In Vivo and In Vitro Ivermectin Resistance in Sarcoptes scabiei. Clin. Infect. Dis. 2004, 39, e8-e12. [CrossRef]

36. Davis, J.S.; McGloughlin, S.; Tong, S.Y.C.; Walton, S.F.; Currie, B.J. A Novel Clinical Grading Scale to Guide the Management of Crusted Scabies. PLoS Negl. Trop. Dis. 2013, 7, e2387. [CrossRef] [PubMed]

37. Mofiz, E.; Seemann, T.; Bahlo, M.; Holt, D.; Currie, B.J.; Fischer, K.; Papenfuss, A.T. Mitochondrial Genome Sequence of the Scabies Mite Provides Insight into the Genetic Diversity of Individual Scabies Infections. PLoS Negl. Trop. Dis. 2016, 10, e0004384 [CrossRef] [PubMed]

38. Mofiz, E.; Holt, D.C.; Seemann, T.; Currie, B.J.; Fischer, K.; Papenfuss, A.T. Genomic resources and draft assemblies of the human and porcine varieties of scabies mites, Sarcoptes scabiei var. hominis and var. suis. GigaScience 2016, 5, 23. [CrossRef] [PubMed]

39. Bolger, A.M.; Lohse, M.; Usadel, B. Trimmomatic: A flexible trimmer for Illumina sequence data. Bioinformatics 2014, 30, 2114-2120. [CrossRef]

40. Zhang, J.; Kobert, K.; Flouri, T.; Stamatakis, A. PEAR: A fast and accurate Illumina Paired-End reAd mergeR. Bioinformatics 2014, 30, 614-620. [CrossRef] [PubMed]

41. Li, H.; Durbin, R. Fast and accurate long-read alignment with Burrows-Wheeler transform. Bioinformatics 2010, 26, 589-595. [CrossRef]

42. Rider, S.D.; Morgan, M.S.; Arlian, L.G. Draft genome of the scabies mite. Parasites Vectors 2015, 8, 1-14. [CrossRef]

43. Altschul, S.F.; Gish, W.; Miller, W.; Myers, E.W.; Lipman, D.J. Basic local alignment search tool. J. Mol. Biol. 1990, 215, 403-410. [CrossRef]

44. Wood, D.E.; Salzberg, S.L. Kraken: Ultrafast metagenomic sequence classification using exact alignments. Genome Biol. 2014, 15, R46. [CrossRef]

45. Buchfink, B.; Xie, C.; Huson, D.H. Fast and sensitive protein alignment using DIAMOND. Nat. Methods 2015, 12, 59-60. [CrossRef] [PubMed]

46. Ondov, B.D.; Bergman, N.H.; Phillippy, A.M. Interactive metagenomic visualization in a Web browser. BMC Bioinform. 2011, 12, 385. [CrossRef]

47. Nurk, S.; Meleshko, D.; Korobeynikov, A.; Pevzner, P.A. metaSPAdes: A new versatile metagenomic assembler. Genome Res. 2017, 27, 824-834. [CrossRef]

48. Kang, D.D.; Li, F.; Kirton, E.; Thomas, A.; Egan, R.; An, H.; Wang, Z. MetaBAT 2: An adaptive binning algorithm for robust and efficient genome reconstruction from metagenome assemblies. Peer] 2019, 7, e7359. [CrossRef] [PubMed] 
49. Parks, D.H.; Imelfort, M.; Skennerton, C.T.; Hugenholtz, P.; Tyson, G.W. CheckM: Assessing the quality of microbial genomes recovered from isolates, single cells, and metagenomes: Supplemental material. UQ eSpace 2015, 25, 1043-1055. [CrossRef]

50. Zhu, W.; Lomsadze, A.; Borodovsky, M. Ab initio gene identification in metagenomic sequences. Nucleic Acids Res. 2010, 38 , e132. [CrossRef] [PubMed]

51. Beghini, F.; McIver, L.J.; Blanco-Míguez, A.; Dubois, L.; Asnicar, F.; Maharjan, S.; Mailyan, A.; Maltez Thomas, A.; Manghi, P.; Valles-Colomer, M.; et al. Integrating taxonomic, functional, and strain-level profiling of diverse microbial communities with bioBakery 3. bioRxiv 2020. [CrossRef]

52. Chen, L.; Yang, J.; Yu, J.; Yao, Z.; Sun, L.; Shen, Y.; Jin, Q. VFDB: A reference database for bacterial virulence factors. Nucleic Acids Res. 2005, 33, D325-D328. [CrossRef] [PubMed]

53. Kaya, H.; Hasman, H.; Larsen, J.; Stegger, M.; Johannesen, T.B.; Allesøe, R.L.; Lemvigh, C.K.; Aarestrup, F.M.; Lund, O.; Larsen, A.R. SCCmecFinder, a Web-Based Tool for Typing of Staphylococcal Cassette Chromosome mec in Staphylococcus aureus Using Whole-Genome Sequence Data. mSphere 2018, 3, e00612-17. [CrossRef]

54. Rawlings, N.D.; Barrett, A.J.; Thomas, P.D.; Huang, X.; Bateman, A.; Finn, R.D. The MEROPS database of proteolytic enzymes, their substrates and inhibitors in 2017 and a comparison with peptidases in the PANTHER database. Nucleic Acids Res. 2018, 46, D624-D632. [CrossRef] [PubMed]

55. Rapp, C.M.; Morgan, M.S.; Arlian, L.G. Presence of host immunoglobulin in the gut of Sarcoptes scabiei (Acari: Sarcoptidae). J. Med. Entomol. 2006, 43, 539-542. [CrossRef]

56. Willis, C.; Currie, B.J.; Walton, S.F.; Kemp, D.J.; Fischer, K. Scabies mite inactivated serine protease paralogues are present both internally in the mite gut and externally in feces. Am. J. Trop. Med. Hyg. 2006, 75, 683-687. [CrossRef] [PubMed]

57. Kenyon, J.J.; Shashkov, A.S.; Senchenkova, S.N.; Shneider, M.M.; Liu, B.; Popova, A.V.; Arbatsky, N.P.; Miroshnikov, K.A.; Wang, L.; Knirel, Y.A.; et al. Acinetobacter baumannii K11 and K83 capsular polysaccharides have the same 6-deoxy- 1 -talose-containing pentasaccharide K units but different linkages between the K units. Int. J. Biol. Macromol. 2017, 103, 648-655. [CrossRef]

58. McMillan, D.J.; Bessen, D.E.; Pinho, M.; Ford, C.; Hall, G.S.; Melo-Cristino, J.; Ramirez, M. Population Genetics of Streptococcus dysgalactiae Subspecies equisimilis Reveals Widely Dispersed Clones and Extensive Recombination. PLoS ONE 2010, 5, e11741. [CrossRef]

59. Enright, M.C.; Day, N.P.J.; Davies, C.E.; Peacock, S.J.; Spratt, B.G. Multilocus Sequence Typing for Characterization of MethicillinResistant and Methicillin-Susceptible Clones of Staphylococcus aureus. J. Clin. Microbiol. 2000, 38, 1008-1015. [CrossRef]

60. Zeighami, H.; Valadkhani, F.; Shapouri, R.; Samadi, E.; Haghi, F. Virulence characteristics of multidrug resistant biofilm forming Acinetobacter baumannii isolated from intensive care unit patients. BMC Infect. Dis. 2019, 19, 1-9. [CrossRef] [PubMed]

61. Davies, M.R.; McMillan, D.J.; Beiko, R.G.; Barroso, V.; Geffers, R.; Sriprakash, K.S.; Chhatwal, G.S. Virulence Profiling of Streptococcus dysgalactiae Subspecies equisimilis Isolated from Infected Humans Reveals 2 Distinct Genetic Lineages That Do Not Segregate with Their Phenotypes or Propensity to Cause Diseases. Clin. Infect. Dis. 2007, 44, 1442-1454. [CrossRef]

62. Foster, T.J. The Staphylococcus aureus "superbug". J. Clin. Invest. 2004, 114, 1693-1696. [CrossRef] [PubMed]

63. Terada, M.; Tsutsui, H.; Imai, Y.; Yasuda, K.; Mizutani, H.; Yamanishi, K.; Kubo, M.; Matsui, K.; Sano, H.; Nakanishi, K. Contribution of IL-18 to atopic-dermatitis-like skin inflammation induced by Staphylococcus aureus product in mice. Proc. Natl. Acad. Sci. USA 2006, 103, 8816-8821. [CrossRef] [PubMed]

64. Yao, Y.; Kozman, A.; Al-Hassani, M.; Saha, C.K.; Yi, Q.; Yao, W.; Mousdicas, N.; Kaplan, M.H.; Travers, J.B. Identification of Staphylococcal Protein A in Infected Atopic Dermatitis Lesions. J. Investig. Dermatol. 2010, 130, 2502-2504. [CrossRef]

65. Godlewska, U.; Brzoza, P.; Kwiecień, K.; Kwitniewski, M.; Cichy, J. Metagenomic Studies in Inflammatory Skin Diseases. Curr. Microbiol. 2020, 77, 3201-3212. [CrossRef] [PubMed]

66. Gebhardt, M.J.; Gallagher, L.A.; Jacobson, R.K.; Usacheva, E.A.; Peterson, L.R.; Zurawski, D.V.; Shuman, H.A. Joint Transcriptional Control of Virulence and Resistance to Antibiotic and Environmental Stress in Acinetobacter baumannii. mBio 2015, 6, e01660-15. [CrossRef]

67. Kim, I.H.; Kim, I.-J.; Wen, Y.; Park, N.-Y.; Park, J.; Lee, K.-W.; Koh, A.; Lee, J.-H.; Koo, S.-H.; Kim, K.-S. Vibrio vulnificus Secretes an Insulin-degrading Enzyme That Promotes Bacterial Proliferation in Vivo. J. Biol. Chem. 2015, 290, 18708-18720. [CrossRef]

68. Walker, K.E.; Moghaddame-Jafari, S.; Lockatell, C.V.; Johnson, D.; Belas, R. ZapA, the IgA-degrading metalloprotease of Proteus mirabilis, is a virulence factor expressed specifically in swarmer cells. Mol. Microbiol. 1999, 32, 825-836. [CrossRef]

69. Speziale, P.; Pietrocola, G. The Multivalent Role of Fibronectin-Binding Proteins A and B (FnBPA and FnBPB) of Staphylococcus aureus in Host Infections. Front. Microbiol. 2020, 11. [CrossRef]

70. Kline, J.B.; Xu, S.; Bisno, A.L.; Collins, C.M. Identification of a fibronectin-binding protein (GfbA) in pathogenic group G streptococci. Infect. Immun. 1996, 64, 2122-2129. [CrossRef] [PubMed]

71. Brandt, C.M.; Spellerberg, B. Human infections due to Streptococcus dysgalactiae subspecies equisimilis. Clin. Infect. Dis. 2009, 49, 766-772. [CrossRef] [PubMed]

72. Joo, H.-S.; Otto, M. Mechanisms of resistance to antimicrobial peptides in staphylococci. Biochim. Biophys. Acta Biomembr. 2015, 1848, 3055-3061. [CrossRef] [PubMed]

73. Aucken, H.; Berlau, J.; Malnick, H.; Pitt, T. Distribution of Acinetobacter Species on Skin of Healthy Humans. Eur. J. Clin. Microbiol. Infect. Dis. 1999, 18, 179-183. [CrossRef]

74. Anstey, N.M.; Currie, B.J.; Withnall, K.M. Community-Acquired Acinetobacter Pneumonia in the Northern Territory of Australia. Clin. Infect. Dis. 1992, 14, 83-91. [CrossRef] [PubMed] 
75. Harding, C.M.; Hennon, S.W.; Feldman, M.F. Uncovering the mechanisms of Acinetobacter baumannii virulence. Nat. Rev. Genet. 2018, 16, 91-102. [CrossRef] [PubMed]

76. Xiao, J.; Zhang, C.; Ye, S. Acinetobacter baumannii meningitis in children: A case series and literature review. Infection 2018, 47, 643-649. [CrossRef] [PubMed]

77. Zurawski, D.V.; Banerjee, J.; Alamneh, Y.A.; Shearer, J.P.; Demons, S.T. Skin and Soft Tissue Models for Acinetobacter baumannii Infection. Methods Mol. Biol. 2019, 1946, 271-287. [CrossRef]

78. Guerrero, D.M.; Perez, F.; Conger, N.G.; Solomkin, J.S.; Adams, M.D.; Rather, P.N.; Bonomo, R.A. Acinetobacter baumanniiAssociated Skin and Soft Tissue Infections: Recognizing a Broadening Spectrum of Disease. Surg. Infect. 2010, $11,49-57$. [CrossRef]

79. Meumann, E.M.; Anstey, N.M.; Currie, B.J.; Piera, K.A.; Kenyon, J.J.; Hall, R.M.; Davis, J.S.; Sarovich, D.S. Genomic epidemiology of severe community-onset Acinetobacter baumannii infection. Microb. Genom. 2019, 5. [CrossRef]

80. Lee, C.-R.; Lee, J.H.; Park, M.; Park, K.S.; Bae, I.K.; Kim, Y.B.; Cha, C.-J.; Jeong, B.C.; Lee, S.H. Biology of Acinetobacter baumannii: Pathogenesis, Antibiotic Resistance Mechanisms, and Prospective Treatment Options. Front. Cell. Infect. Microbiol. 2017, 7, 55. [CrossRef]

81. Weidensdorfer, M.; Ishikawa, M.; Hori, K.; Linke, D.; Djahanschiri, B.; Iruegas, R.; Ebersberger, I.; Riedel-Christ, S.; Enders, G.; Leukert, L.; et al. The Acinetobacter trimeric autotransporter adhesin Ata controls key virulence traits of Acinetobacter baumannii. Virulence 2019, 10, 68-81. [CrossRef]

82. Antimicrobial Resistance. Available online: https://www.who.int/news-room/fact-sheets/detail/antimicrobial-resistance (accessed on 28 February 2021).

83. Baracco, G.J. Infections Caused by Group C and G Streptococcus (Streptococcus dysgalactiae subsp. equisimilis and Others): Epidemiological and Clinical Aspects. Microbiol. Spectr. 2019, 7. [CrossRef]

84. Heng, N.C.K.; Ragland, N.L.; Swe, P.M.; Baird, H.J.; Inglis, M.A.; Tagg, J.R.; Jack, R.W. Dysgalacticin: A novel, plasmid-encoded antimicrobial protein (bacteriocin) produced by Streptococcus dysgalactiae subsp. equisimilis. Microbiology 2006, 152, $1991-2001$. [CrossRef] [PubMed]

85. Lowy, F.D. Staphylococcus aureus Infections. N. Engl. J. Med. 1998, 339, 520-532. [CrossRef] [PubMed]

86. Tong, S.Y.C.; Davis, J.S.; Eichenberger, E.; Holland, T.L.; Fowler, V.G., Jr. Staphylococcus aureus Infections: Epidemiology, Pathophysiology, Clinical Manifestations, and Management. Clin. Microbiol. Rev. 2015, 28, 603-661. [CrossRef] [PubMed]

87. Tong, S.Y.; Bishop, E.J.; Lilliebridge, R.A.; Cheng, A.C.; Spasova-Penkova, Z.; Holt, D.C.; Giffard, P.M.; McDonald, M.I.; Currie, B.J.; Boutlis, C.S. Community-associated strains of methicillin-resistant Staphylococcus aureus and methicillin-susceptible S. aureus in indigenous Northern Australia: Epidemiology and outcomes. J. Infect. Dis. 2009, 199, 1461-1470. [CrossRef] [PubMed]

88. Merialdi, G.; Feltrin, F.; Gaetarelli, B.; Lombardi, G.; Iurescia, M.; Alba, P.; Luppi, A.; Martinelli, N.; Ramini, M.; Carfora, V.; et al. Livestock-associated methicillin-resistant Staphylococcus aureus (LA-MRSA) spa type t127, Sequence Type (ST)1, quickly spreads and persists among young pigs. Pathog. Dis. 2019, 77. [CrossRef]

89. Flores-Mireles, A.L.; Walker, J.N.; Caparon, M.; Hultgren, S.J. Urinary tract infections: Epidemiology, mechanisms of infection and treatment options. Nat. Rev. Microbiol. 2015, 13, 269-284. [CrossRef]

90. Spernovasilis, N.; Psichogiou, M.; Poulakou, G. Skin manifestations of Pseudomonas aeruginosa infections. Curr. Opin. Infect. Dis. 2021, 34, 72-79. [CrossRef]

91. Swe, P.M.; Zakrzewski, M.; Kelly, A.; Krause, L.; Fischer, K. Scabies Mites Alter the Skin Microbiome and Promote Growth of Opportunistic Pathogens in a Porcine Model. PLoS Negl. Trop. Dis. 2014, 8, e2897. [CrossRef]

92. Chen, Y.E.; Fischbach, M.A.; Belkaid, Y. Skin microbiota-host interactions. Nature 2018, 553, 427-436. [CrossRef] [PubMed]

93. Koga, R.; Tsuchida, T.; Sakurai, M.; Fukatsu, T. Selective elimination of aphid endosymbionts: Effects of antibiotic dose and host genotype, and fitness consequences. FEMS Microbiol. Ecol. 2007, 60, 229-239. [CrossRef] [PubMed]

94. Hardie, J.; Leckstein, P. Antibiotics, primary symbionts and wing polyphenism in three aphid species. Insect Biochem. Mol. Biol. 2007, 37, 886-890. [CrossRef]

95. Bandi, C.; McCall, J.W.; Genchi, C.; Corona, S.; Venco, L.; Sacchi, L. Effects of tetracycline on the filarial worms Brugia pahangi and Dirofilaria immitis and their bacterial endosymbionts Wolbachia. Int. J. Parasitol. 1999, 29, 357-364. [CrossRef]

96. Swe, P.M.; Zakrzewski, M.; Waddell, R.; Sriprakash, K.S.; Fischer, K. High-throughput metagenome analysis of the Sarcoptes scabiei internal microbiota and in-situ identification of intestinal Streptomyces sp. Sci. Rep. 2019, 9, 1-11. [CrossRef]

97. Bouvresse, S.; Socolovshi, C.; Berdjane, Z.; Durand, R.; Izri, A.; Raoult, D.; Chosidow, O.; Brouqui, P. No evidence of Bartonella quintana but detection of Acinetobacter baumannii in head lice from elementary schollchildren in Paris. Comp. Immunol. Microbiol. Infect. Dis. 2011, 24, 475-477. [CrossRef] [PubMed]

98. Kempf, M.; Abdissa, A.; Diatta, G.; Trape, J.-F.; Angelakis, E.; Mediannikov, O.; La Scola, B.; Raoult, D. Detection of Acinetobacter baumannii in human head and body lice from Ethiopia and identification of new genotypes. Int. J. Infect. Dis. 2012, 16, e680-e683. [CrossRef] [PubMed]

99. Sunantaraporn, S.; Sanprasert, V.; Pengsakul, T.; Phumee, A.; Boonserm, R.; Tawatsin, A.; Thavara, U.; Siriyasatien, P. Molecular survey of the head louse Pediculus humanus capitis in Thailand and its potential role for transmitting Acinetobacter spp. Parasites Vectors 2015, 8, 127. [CrossRef]

100. Mana, N.; Louni, M.; Parola, P.; Bitam, I. Human head lice and pubic lice reveal the presence of several Acinetobacter species in Algiers, Algeria. Comp. Immunol. Microbiol. Infect. Dis. 2017, 53, 33-39. [CrossRef] 
101. Mokhtar, A.S.; Lau, Y.L.; Wilson, J.-J.; Abdul-Aziz, N.M. Genetic Diversity of Pediculus humanus capitis (Phthiraptera: Pediculidae) in Peninsular Malaysia and Molecular Detection of Its Potential Associated Pathogens. J. Med. Entomol. 2020, 57, 915-926. [CrossRef]

102. Boumbanda-Koyo, C.S.; Mediannikov, O.; Amanzougaghene, N.; Oyegue-Liabagui, S.L.; Imboumi-Limoukou, R.K.; Raoult, D.; Lekana-Douki, J.B.; Fenollar, F. Molecular identification of head lice collected in Franceville (Gabon) and their associated bacteria. Parasites Vectors 2020, 13, 1-8. [CrossRef] [PubMed]

103. La Scola, B.; Raoult, D. Acinetobacter baumannii in human body louse. Emerg. Infect. Dis. 2004, 10, 1671-1673. [CrossRef] [PubMed] 